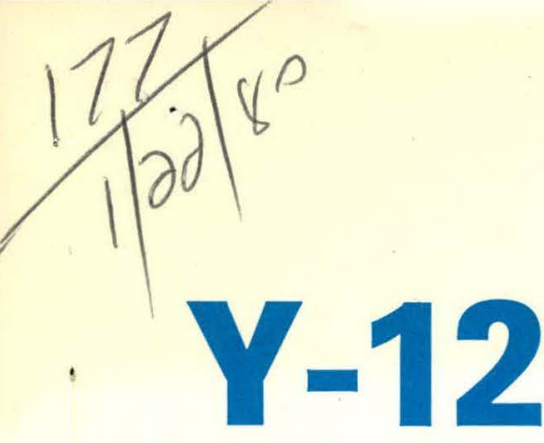

\section{OAK} RIDGE Y-12 PLANT CARBIDE

\section{th. 549}

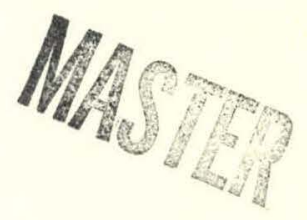

Y-2194

\section{DETERMINATION OF HYDROGEN IN URANIUM-NIOBIUM-ZIRCONIUM ALLOY BY INERT-GAS FUSION}

W. F. Carden
OPERATED BY

UNION CARBIDE CORPORATION FOR THE UNITED STATES DEPARTMENT OF ENERGY 


\section{DISCLAIMER}

This report was prepared as an account of work sponsored by an agency of the United States Government. Neither the United States Government nor any agency Thereof, nor any of their employees, makes any warranty, express or implied, or assumes any legal liability or responsibility for the accuracy, completeness, or usefulness of any information, apparatus, product, or process disclosed, or represents that its use would not infringe privately owned rights. Reference herein to any specific commercial product, process, or service by trade name, trademark, manufacturer, or otherwise does not necessarily constitute or imply its endorsement, recommendation, or favoring by the United States Government or any agency thereof. The views and opinions of authors expressed herein do not necessarily state or reflect those of the United States Government or any agency thereof. 


\section{DISCLAIMER}

Portions of this document may be illegible in electronic image products. Images are produced from the best available original document. 
Reference to a company or product name does not imply approval or recommendation of the product by Union Carbide Corporation or the Department of Energy to the exclusion of others that may meet specifications.

Printed in the United States of America. Available from National Technical Information Service

U.S. Department of Commerce 5285 Port Royal Road, Springfield, Virginia 22161

Price: Printed Copy A02; Microfiche A01

This report was prepared as an account of work sponsored by an agency of the United States Government. Neither the United States Government nor any agency thereof, nor any of their employees, nor any of their contractors, subcontractors, or their employees, makes any warranty, express or implied, nor assumes any legal liability or responsibility for any third party's use or the results of such use of any information, apparatus, product or process disclosed in this report, nor represents that its use by such third party would not infringe privately owned rights. 
Date of Issue: December 31, 1979

Distribution Category: UC-4

\title{
DETERMINATION OF HYDROGEN IN URANIUM-NIOBIUM-ZIRCONIUM ALLOY BY INERT-GAS FUSION
}

\author{
W. F. Carden
}

Plant Laboratory Department

Y-12 Product Certification Division

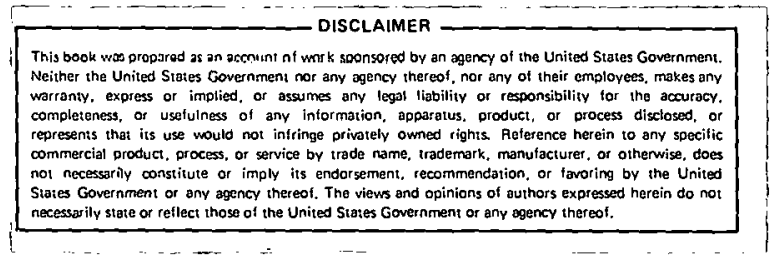

Oak Ridge $Y-12$ Plant

P. O. Box Y, Oak Ridge, Tennessee 37830

Prepared for the Department of Energy

Under US Government Contract W-7405-eng-26 


\section{ABSTRACT}

An improved method has been developed using inert-gas fusion for determining the hydrogen content in uranium-niobium-zirconium (U-7.5Nb-2.5Zr) alloy. The method is applicable to concentrations of hydrogen ranging from. 1 - 250 micrograms per gram and may be adjusted for analysis of greater hydrogen concentrations. Hydrogen is determined using a hydrogen determinator. The limit of error for a single determination at the $95 \%$-confidence level (at the $3.7-\mu \mathrm{g} / \mathrm{g}$-hydrogen level) is $\pm 1.4 \mathrm{micrograms}$ per gram hydrogen. 
CONTENTS

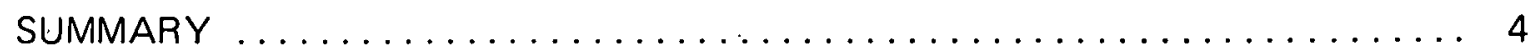

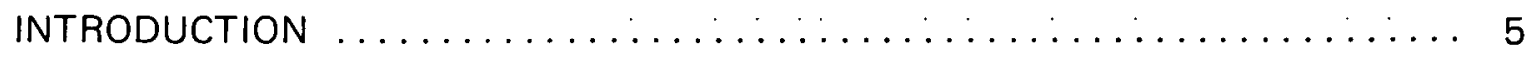

RESOLUTION OF HYDROGEN IN URANIUM-NIOBIUM-ZIRCONIUM ALLOY ... . 6

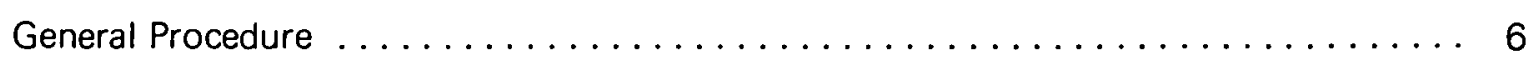

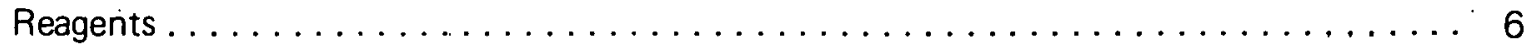

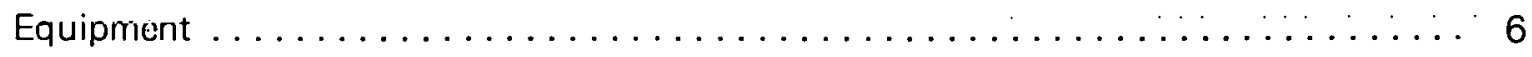

Funstinns and Preparation of Equipment $\ldots \ldots \ldots \ldots \ldots \ldots \ldots \ldots \ldots \ldots \ldots \ldots \ldots \ldots \ldots \ldots \ldots$

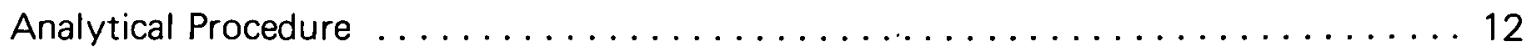

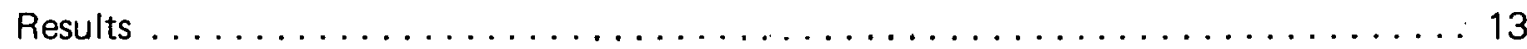

ACKNOWLEDGMENTS $\ldots \ldots \ldots \ldots \ldots \ldots \ldots \ldots \ldots \ldots \ldots \ldots \ldots \ldots \ldots \ldots \ldots$ 


\section{SUMMARY}

The Leco RH1 Hydrogen Determinator(a) utilizes an inert-gas-fusion technique; hydrogen is determined by measuring the output of a thermal-conductivity cell.

The sample is fused in an argon atmosphere at high temperature (approximately $1900^{\circ} \mathrm{C}$ ) in a single-use graphite crucible to release hycurogen and other gases. Argon carries the gases through a chromatographic column, which separates the hydrogen from other released gases, into a thermistor cell where hydrogen is determined by thermal conductivity of the gas. The hydrogen content is read directly in parts per million from an electronic digital voltmeter.

The limit of error at the 95\%-confidence level for a single determination of hydrogen in uranium-niobium-zirconium $(U-7.5 \mathrm{Nb}-2.5 \mathrm{Zr})$ alloy at the 3.7-micrograms-per-gramhydrogen level is \pm 1.4 micrograms per gram hydrogen.

(a) Instruction Manual, RH1 Hydrogen Determinator Models 760-300 and 760-800 (BCD); Leco Corporation, St. Joseph, Michigan (1974). 


\section{INTRODUCTION}

Since hydrogen in uranium-niobium-zirconium (U-7.5Nb-2.5Zr) alloy tends to embrittle the alloy, it is necessary to establish a fast and accurate method for determining the hydrogen content.

Previous procedures using a thermal-diffusion technique required elapsed times up to one hour for the determination of hydrogen. content in one aliquant. At the Oak Ridge Y-12 Plant, (b) a new instrument with an inert-gas-fusion technique is used. The hydrogen percentage of a single aliquant is determined in approximately two minutes with the faster and more reliable method of analysis.

(b) Operated by the Union Carbide Corporation's Nuclear Division for the Department of Energy. 


\section{RESOLUTION OF HYDROGEN IN URANIUM-NIOBIUM-ZIRCONIUM ALLOY}

\section{GENERAL PROCEDURE}

Hydrogen is determined in uranium-niobium-zirconium (U-7.5Nb-2.5Zr) alloy using a Leco Model RH1 Hydrogen Determinator. The determinator utilizes an inert-gas-fusion technique, whereby the sample is fused in an argon atmosphere at a high temperature $\left(\sim 1900^{\circ} \mathrm{C}\right)$ inside a single-use graphite crucible to release hydrogen and other gases. Argon carries the released gases through a chromatographic column (where hydrogen is separated from the remaining gases) into a thermistor cell. There, hydrogen is determined by thermal conductivity; and hydrogen content is read directly in parts per million from an electronic voltmeter. The limit of error for a single hydrogen determination in a National Bureau of Standards (NBS) titanium standard at the 95\%-confidence level is 2 micrograms per gram at 32-micrograms-per-gram-hydrogen level.

\section{REAGENTS}

The following reagents are required in this general procedure:

Acetone (reagent grade)

Magnesium perchlorate (reagent grade)

Argon (high-purity gas, 99.997\%)

Ascarite $^{(\mathrm{c})}$ [sodium hydroxide $(\mathrm{NaH})$ on asbestos]

Nickel shot

Schutze reagent (Leco 761-747 or equivalent)

Standards (hydrogen in titanium)

\begin{tabular}{|c|c|}
\hline $\begin{array}{c}\text { NBS } \\
\text { Standards }\end{array}$ & $\begin{array}{l}\text { Hydrogen } \\
\qquad(\mu \mathrm{g} / \mathrm{g})\end{array}$ \\
\hline 352 & 32 \\
\hline 353 & 98 \\
\hline 354 & 215 \\
\hline
\end{tabular}

Tin, flux (Leco $761-739$ or equivalent)

\section{EQUIPMENT}

The following equipment is utilized in this procedure:

Balance, analytical

Capsules, tin (Leco 501-059 or equivalent)

(c) Arthur H. Thomas Company, Philadelphia, Pennsylvania. 
Crucibles, carbon (Leco $760-414$ or equivalent)

Cutter, sample

Determinator, Leco RH1 Hydrogen Determinator, Model 760-300, Figure 1

Files, taper (6-inch length)

mill (10-inch length)

Forceps, stainless steel with platinum tips

Glass wool (Leco 501-081 or equivalent)

\section{TUNCTIONS AND PREPARATION OF EQUIPMENT}

\section{Function of the Hydrogen Determinator Components}

The Leco RH1 Hydrogen Determinator consists of three basic components; the impulse furnace, the reagent system, and the analytical integration system (Figure 1).

1. The impulse furnace heats the sample and crucible to approximately $1900^{\circ} \mathrm{C}$. The furnace is connected to a sample-loading head and to the analytical section through the reagent system.

2. The reagent system transfers the gases liberated from the sample in the crucible to the analytical section where hydrogen is determined. The gases released (primarily hydrogen, nitrogen, and oxygen) pass through a dust filter before entering the reagent columns. Nitrogen and oxygen are separated from hydrogen before it enters the thermal conductivity cell for measurement. Oxygen (liberated from the sample) is converted to carbon monoxide ( $\mathrm{CO}$ ) by carbon from the graphite crucible. The $\mathrm{CO}$ is oxidized to carbon dioxide $\left(\mathrm{CO}_{2}\right)$ in a column of Schutze reagent without oxidizing hydrogen to water. The $\mathrm{CO}_{2}$ is then trapped in a column of Ascarite ( $\mathrm{NaOH}$ over asbestos). A column of magnesium-perchlorate $\left[\mathrm{Mg}\left(\mathrm{ClO}_{4}\right)_{2}\right]$ traps the water formed and removes it from the hydrogen gas. When the Sichutze reagent becomes depleted, there is a change in color from yellow to dark brown. Depletion of Ascarite is indicated by a damp area. Nitrogen is separated from hydrogen in a molecular-sieve chromatographic column. Hydrogen gas is eluted first, then nitrogen is eluted approximately 2 minutes later.

3. The analytical integration system measures the amount of hydrogen in the sample. When the hydrogen enters the measuring cell of the thermistor bridge, the bridge output is integrated and displayed directly as total micrograms of hydrogen per sample on an electronic voltmeter.

\section{Function of Hydrogen Determinator Controls}

1. Power On Switch controls electrical power to the determinator. This switch should be left on at all times except for required electrical maintenance. 


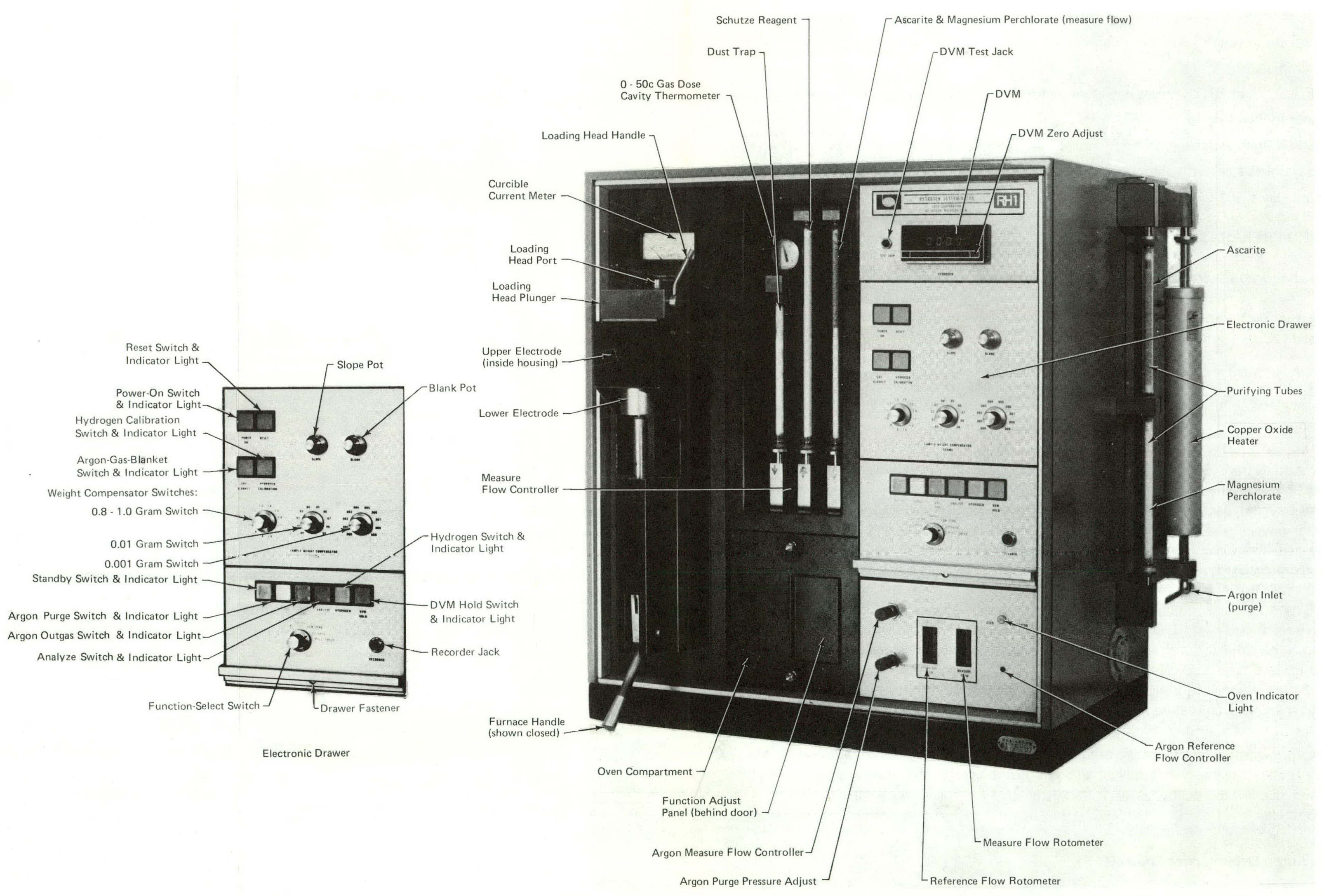

Figure 1. LECO RH1 HYDROGEN DETERMINATOR. 
2. Crucible Current Meter indicates the amount of electrical current being delivered to the crucible during ignition.

3. Hydrogen Digital-Voltmeter Switch controls electrical power to the hydrogen digital voltmeter.

4. Standby Switch controls electrical power to de-energize solenoid for shutdown procedure.

5. Purge Switch controls Leco RH1 argon purge during sample and crucible loading.

6. Outgas Switch controls Leco RH1 argon outgas after sample and crucible loading; controls furnace outgassing of crucible.

7. Analyze Switch controls electrical power used to heat crucible and sample in furnace.

8. Hydrogen Switch controls electrical power used to integrate total hydrogen and to record on hydrogen voltmeter.

9. Function-Select Switch selects the proper mode, operational or checkout.

10. Digital-Voltmeter-Test Jack is for function-adjust panel for electronic checkout.

11. Argon Purge-Flow Needle Valve controls argon flow to purge system. This valve is normally adjusted to $15 \pm 1$ psi on pressure gage located inside the electronics drawer.

12. Argon Measure-Flow Controller controls the argon flow to the measure system. This valve is normally adjusted for a reading of 150 on the measure flow rotometer.

13. Argon Reference-Flow Controller controls the argon flow to the reference system. This valve is normally adjusted for a reading of 80 on the reference rotometer.

14. Argon Control Regulator is mounted on an argon cylinder and controls the flow of argon into the hydrogen determinator. Adjust the regulator for 40 psi.

15. Argon-Blanket Indicator Switch controls argon flow to the sample in loading head. Argon blanket control switch should be off when the instrument is operated normally.

16. Reset Switch controls outgas cycle without heating the crucible. Do not activate reset switch in normal operation.

17. Digital-Voltmeter Hold (DVM Hold) Switch controls retention of hydrogen reading on digital voltmeter. The digital voltmeter should be on when the instrument is operated.

18. Weight Compensator Switch should be set on 1 for this procedure. 


\section{Preparation of Hydrogen Determinator Equipment}

1. Coolant Circulator. Check the water supply to the coolant circulator to ensure water supply is available.

Energize the coolant circulator power switch.

2. Hydrogen Determinator. "Change glass-wool dust trap at the beginning of each operative day.

Change Schutze reagent, Ascarite, and $\left.\left[\mathrm{Mg}_{(\mathrm{ClO}}\right)_{2}\right]$ in the tubes as needed.

DVM hold switch must be on.

Function select switch must be in the operate position.

The two circuit breakers located on the rear of the determinator must be on.

The standby indicator must be green.

The gas blanket indicator must be off.

The furnace must be empty and closed.

The oven indicator must be cycling on and off, and the oven temperature must be approximately $45^{\circ} \mathrm{C}$.

The argon regulator must be set for 40 psi by turning the argon-cylinder valve in a counterclockwise direction and the gas-regulator valve in a clockwise direction.

The measure flow must indicate an approximate flow scale reading of 150 .

The reference flow must indicate an approximate flow scale reading of 80 .

3. Instrument Start-Up. Open the furnace by pulling the furnace handle upward. The purge indicator will turn white, and the standby indicator will deactivate.

Inspect the interior of the upper electrode cavity with a mirror and a light to ensure the system is free from deposits. Clean the electrode with a metal-bristle brush and cleansing tissue.

Inspect the lower electrode. The bottom center of the lower cup must be free from all sample metal or graphite particles. Clean the electrode with a metal-bristle brush and cleansing tissue.

Add approximately one gram of tin discs and approximately one grain of nickel shot to each crucible to be used in this analysis. (These crucibles may be prepared in advance.) In order not to contaminate the crucible when placing it on the lower electrode assembly, handle it with forceps.

Close the furnace by depressing the furnace handle. The purge indicator will turn green.

The furnace must be kept closed at all times except when cleaning the interior of the furnace or loading the crucible.

The furnace must be thoroughly cleaned before each aliquant.

The hydrogen determinator is now ready for calibration. 
4. Calibration of RH1 Hydrogen Determinator.

(a) Determination of Hydrogen Crucible Blank.

Depress the outgas switch. The outgas indicator will be white during the outgas period, and the purge indicator will be off.

The crucible-current value is indicated on the furnace power meter; and during outgas, the meter should indicate 600 to 800 amperes.

When the outgas indicator turns green, rotate the loading-head handle $180^{\circ}$ counterclockwise to the down position. This simulates the drop of a sample or blank into the carbon crucible.

Depress the analyze switch. The outgas indicator will deactivate, and the analyze indicator will turn white.

When the hydrogen indicator turns green, the value of hydrogen will be displayed on the digital voltmeter:

Open the furnace by raising the furnace handle which releases the lower electrode. Remove the crucible using forceps, and clean the furnace with a copper brush and cleansing tissues.

The blank for hydrogen must read 0 or 1 on the digital voltmeter.

If the blank does not fall in the required limits after two determinations, adjust the blank-pot potentiometer for hydrogen while the hydrogen indicator is white in order to maintain all zeroes on the digital voltmeter. Do not attempt to adjust the hydrogen blank after the hydrogen indicator turns green.

Run the tin capsule blank after loading a folded, tin capsule blank in the loading head.

(b) Calibration Using NBS Reference Materials.

Degrease NBS standards in acetone, dry, weigh on an analytical balance, and record the weight of each standard. Analyze the NBS standards as in Table 1.

Table 1

NATIONAL BUREAU OF STANDARDS

HYDROGEN DETERMINATION

REFERENCE MATERIALS

\begin{tabular}{cccc}
\hline $\begin{array}{c}\text { NBS } \\
\text { Standard }\end{array}$ & $\begin{array}{c}\text { Hydrogen } \\
(\%)\end{array}$ & $\begin{array}{c}\text { Hydrogen } \\
\mu \mathrm{g} / \mathrm{g} \text { Sample }\end{array}$ & $\begin{array}{c}\text { Limits } \\
(\mu \mathrm{g})\end{array}$ \\
\hline 353 & 0.0098 & 98 & \pm 10 \\
352 & 0.0032 & 32 & \pm 3 \\
\hline
\end{tabular}

Open the sample-loading head by pulling the cylinder handle to the right and placing an NBS standard in the sample cavity. Close the loading head by pushing the cylinder to the left:

Proceed with each standard. 
Calculate the standard values using the following equation:

$$
M_{2}=\frac{\mathrm{CH}_{2}-\mathrm{CH}_{2} \text { blank }}{W}
$$

where:

$\mathrm{MH}_{2}=$ micrograms of hydrogen per gram of standard,

$\mathrm{CH}_{2}=$ hydrogen counts for the standard,

$\mathrm{C}_{2}$ blank = hydrogen counts for the hydrogen blank, and

$W=$ weight of the standard in grams.

If the standard values do not fall within the specified limits after two determinations of the first standard, adjust the correct values by adjusting the slope-pot potentiometer.

Repeat the procedure for the next standard. If the slope-pot potentiometer has to be adjusted to meet the prescribed limits, then analyze the first standard until all standards are within the prescribed limits without further adjustment of the slope-pot potentiometer.

Proceed with the analysis of unknown samples for hydrogen.

\section{ANALYTICAL PROCEDURE}

\section{Sample Preparation}

Remove all surface scale and oxidation from the $U-7.5 \mathrm{Nb}-2.5 \mathrm{Zr}$ by abrading metal sample with a file. Do not subject the sample to excessive heat during preparation. Cut the sample into small pieces with a sample cutter. A solid-metal sample aliquant should be no greater than a 1/4-inch cube.

Rinse the sample in acetone and dry.

Store the sample in a glass screw-cap bottle. NOTE: Prepare the sample immediately before analysis.

Weigh duplicate aliquants of $\approx 0.2$ gram each, and store in labeled sample vials for analysis.

\section{Sample Analysis}

Place a prepared sample in the sample-loading head of the furnace.

Repeat steps in the "Determination of Hydrogen Crucible Blank" for the analysis. [See 4.(a) on Page 11 in this report.]

Repeat the preceding steps until all the prepared samples are analyzed. 


\section{Preparation of Instrument for Standby}

Using handle, open the furnace which releases the lower electrode. Remove the crucible with forceps, and clean the furnace with a copper brush and cleansing tissues.

Close the furnace and push the standby switch. The light will glow green indicating that the instrument is in standby.

Turn off the electrical switch to the coolant circulator.

Turn off the argon supply by turning the cylinder valve clockwise until valve is completely closed.

\section{Hydrogen Calculation}

Calculate the micrograms of hydrogen per gram of sample in the unknown sample by using the following equation:

$$
M_{H_{2}}=\frac{C_{H_{2}}-C_{H_{2}} \text { blank }}{W}
$$

where:

$\mathrm{MH}_{2}=$ micrograms of hydrogen per gram of sample, $\mathrm{CH}_{2}=$ hydrogen counts for the sample,

$\mathrm{CH}_{2}$ blank = hydrogen counts for the hydrogen blank, and $W=$ weight of the sample in grams.

\section{RESULTS}

Prccision of Results

A series of aliquants were analyzed to evaluate the precision of a 32- $\mu \mathrm{g} / \mathrm{g}$-hydrogen standard. At the 95\%-confidence level, the limit of error for a single determination is $2 \mu \mathrm{g} / \mathrm{g}$ for hydrogen at the $32-\mu \mathrm{g} / \mathrm{g}$-hydrogen level.

The U-7.5 Nb-2.5Zr alloy was analyzed 26 times for hydrogen, resulting in a hydrogen value of $3.7 \mu \mathrm{g} / \mathrm{g}$. The limit of error at the $95 \%$-confidence level for a single determination at the $3.7-\mu \mathrm{y} / \mathrm{y}$ level is $\pm 1.4 \mu \mathrm{y} / \mathrm{g}$. 


\section{ACKNOWLEDGMENTS}

The author would like to thank H. G. King, Jr for his suggestions and comments during the preparation of this report. 


\section{Distribution}

Department of Energy : Oak Ridge

Hickman, H. D.

Leed, R. E.

Poteat, R. M.

Oak Ridge Gaseous Diffusion Plant

Armstrong, R. C.

Stief, S. S.

Wilcox, W. J., Jr

Uak Kidge Y.12 Plant

Andrew, R. E.

Bernander, N. $K$.

Briscoe, O.W.

Carden, W. F. (10)

Cole, S. H.

Dodson, W. H./Googin, J. M.

Dorsey. J. G.

Franklin, J. C.

Fraser, R. J.

Golson, T. J.

Keith A.

Kent, R. H.

King, H. G., Jr

Kite, H. T. (20)

Mills, J. M., Jr

White, J. C.

Y-12 Central Files (master copy)

$Y-12$ Central Files (route copy)

$Y-12$ Central Files ( $Y-12 R C)$

$Y$-12 Central Files (5)

Paducah Gaseous Diffusion Plant

Bewley, H. U.

In addition, this report is distributed in accordance with the Category UC-4, Chemistry, as given in the Standard Distribution for Unclassified Scientific and Technical Reports, DOE/TIC -4500 . 